\title{
DNA LOOP DOMAIN REARRANGEMENTS IN BLAST TRANSFORMED HUMAN LYMPHOCYTES AND LYMPHOID LEUKAEMIC JURKAT T CELLS
}

\author{
K. AFANASIEVA', V. OLEFIRENKO ${ }^{1}$, A. MARTYNIAK ${ }^{1}$, \\ L. LUKASH ${ }^{2}$, A. SIVOLOB ${ }^{1 凶}$ \\ ${ }^{1}$ Taras Shevchenko National University of Kyiv, Ukraine; \\ ${ }^{2}$ Institute of Molecular Biology and Genetics, \\ National Academy of Sciences of Ukraine, Kyiv; \\ 凶e-mail:sivolob@univ.kiev.ua
}

Received: 06 April 2020; Accepted: 25 June 2020

\begin{abstract}
Chromatin loops are important elements of both chromatin higher-order structure and transcription regulation system. Our previous works showed that several features of the loop domain organization could be investigated by single cell gel electrophoresis (the comet assay) using the kinetic approach. In this study we applied this technique to study DNA loop domain organization in lymphoid cells: human lymphocytes, lymphoblasts cultivated during $24 \mathrm{~h}$ and $44 \mathrm{~h}$, and T cells of Jurkat cell line. Two features of the loop domain organization were found to depend on the cell functional state. First, DNA fraction in the loops of large sizes (more than $200 \mathrm{~kb}$ ) was essentially increased in proliferating (de-differentiated) cells in comparison with terminally differentiated lymphocytes. Second, the linear density of the loops not larger than $200 \mathrm{~kb}$ was decreased in transcriptionally active cells and was increased upon their inactivation.
\end{abstract}

Ke y wo rd s: DNA loops, comet assay, lymphocytes, lymphoblasts, Jurkat cells.

L oop domains are important elements of chromatin higher-order structure [1-4]. The loops are known to appear in an active process of extrusion through the cohesin complex, the extrusion is terminated by CCCTC-binding factors (CTCF proteins) [5-10]. Since promoters and enhancers often occur at the loop ends the chromatin loop domains are thought to be one of the key components of the transcription regulation system $[1-4,11]$. The loop domains are likely to be dynamic structures $[4,6,12]$ and the loop organization has reported to vary in cells of different types $[2,10,13-$ 15]. It thus can be assumed that changes in the loop organization may accompany the processes of cell differentiation and de-differentiation [16, 17].

We have developed recently a simple approach to test the loop domain organization (reviewed in [18]). The approach is based on kinetic measurements of electrophoretic track formation in single cell gel electrophoresis (the comet assay) [18-21]. We have shown that the electrophoretic track (the comet tail) formed by nucleoids (cells lysed in presence of detergents and high salt) mainly consists of supercoiled DNA loops [19, 20]. Our results allowed us to make a conclusion that these loops originate from chromatin loops. In other words, large-scale features of the loop organization are preserved in nucleoids obtained after cell lysis [20, 21]. Our analysis of the two parameters that change during electrophoresis, the relative amount of DNA in the comet tail and the tail length, makes it possible to obtain two quantitative characteristics: (i) to divide all the loops into three subsets - loops on the nucleoid surface, inner loops inside the nucleoid, and very large loops (longer than 200 kb) that cannot migrate [20, 21]; (ii) to estimate the loop size distribution and the average linear density of the loops as its main parameter [20, 22]. In our previous work we have shown that the two characteristics depend on the cell type and/or the cell functional state: in particular, a loop

(C) 2020 Afanasieva K. et al. This is an open-access article distributed under the terms of the Creative Commons Attribution License, which permits unrestricted use, distribution, and reproduction in any medium, provided the original author and source are credited. 
redistribution was observed in human lymphocytes after their activation (blast transformation) with interleukin 2 [22].

Here we investigate this issue in more details in order to compare the loop domain organization in normal lymphocytes, lymphoblasts at different times after activation with interleukin 2, and also malignant lymphoid T cells of the Jurkat cell line. Our results show that the cell functional state and the loop domain organization are closely interrelated and that there are clear signatures, which discriminate terminally differentiated and proliferating cells as well as cells with different levels of transcriptional activity.

\section{Materials and Methods}

Cell isolation and cultivation. Human lymphocytes were isolated from peripheral blood of healthy donors by separation in a density gradient Histopaque 1077 (Sigma, USA) as described previously $[19,20]$. Cells were washed in $0.15 \mathrm{M} \mathrm{NaCl}$ twice and used to prepare samples for the comet assay (see below).

To prepare transformed lymphocytes (lymphoblasts) they were washed twice in Hank's balanced salt solution and then cultivated at $37^{\circ} \mathrm{C}$ in RPMI 1640 medium, supplemented by antibiotics and 10\% fetal bovine serum (Gibco, USA), in presence of recombinant interleukin 2 (1000 units/ml, Biotechpharm, Russia). Two kinds of lymphoblasts were used: cultivated for 24 and $44 \mathrm{~h}$. After the cultivation cells were precipitated by centrifugation, washed in Hank's salt solution and used for sample preparation (see below). Aliquots of the cell suspensions were used for a flow cytometry cell cycle analysis.

Jurkat cells were cultivated in RPMI 1640 medium which contained 10\% fetal bovine serum and antibiotics. Before sample preparation cells were put in the same medium without serum, incubated for $24 \mathrm{~h}$, and then washed in Hank's balanced salt solution. To estimate cell viability a propidium iodide staining was used: equal volumes of the cell suspension and $1 \mathrm{mg} / \mathrm{ml}$ propidium iodide were mixed and the fraction of stained (dead) cells was calculated with a fluorescent microscope (LOMO, Russia). The cultures with the fraction of dead cells not higher than $10 \%$ were used in our experiments.

Sample preparation and electrophoresis. Cells were immobilized in $0.67 \%$ low-melting point agarose (Sigma, USA) on a surface of a microscope slide that was previously covered with $1 \%$ high-melting point agarose. Slides were immersed in ice-cold lysis solution (2.5 M NaCl, $100 \mathrm{mM}$ EDTA, $10 \mathrm{mM}$
Tris-HCl (pH 7.5), 1\% Triton X-100 (Ferak, Germany)) for several hours. Before electrophoresis slides were washed by TBE buffer ( $89 \mathrm{mM}$ Tris-borat, 2 mM EDTA, $\mathrm{pH}$ 7.5) and then electrophoresed in the same buffer in dark at $4^{\circ} \mathrm{C}$ as was described earlier $[19,20]$. To measure the kinetics of the comet formation, several slides were placed into the electrophoresis tank and then they were taken out at different time of electrophoresis for further analysis.

Microscopy and data analysis. After electrophoresis slides were stained with $1.3 \mu \mathrm{g} / \mathrm{ml}$ of DAPI (4',6-diamidino-2-phenylindole, Sigma, USA) and analyzed with a fluorescent microscope connected with a camera Canon EOS 1000 D. 100 to 200 randomly chosen nucleoids were examined on each slide using CometScore (TriTec, USA). Two parameters were determined: the relative amount of DNA in the tails and the tail length. The first was defined as the ratio of the tail fluorescence intensity to the total intensity of the comet, the second - as the distance from the center of mass of the comet head to the distal end of the tail. The tail length was multiplied by two and divided by $0.34 \mathrm{~nm}$ to estimate the contour length of the longest loops in the tail in base pairs.

Kinetic plots (the relative amount $f$ of DNA in the tail versus electrophoresis time t) were analyzed as before (see [20-22] for details): the plots were fitted with the equation $f=A_{1} f_{1}+A_{2} f_{2}$, where $A_{1}$ and $A_{2}$ are the maximum amplitudes of two components ( $A_{2}$ may be equal to zero). The functions $f_{1}$ and $f_{2}$ are described by a standard equation of monomolecular kinetics

$$
f_{1}=1-\exp \left(-k_{1} t\right)
$$

where $k_{1}$ is the rate constant, and the sigmoidal Boltzmann equation

$$
f_{2}=1 /\left[1+\exp \left(k_{2}\left(t_{0}-t\right)\right)\right],
$$

where $k_{2}$ is the rate constant, $t_{0}$ is the transition halftime.

The correlation plots of the amount $f$ versus the contour length $L_{\mathrm{m}}$ of the largest loops in the tail (estimated from the tail length) were analyzed as described [22]. Briefly, $f$ as a function of $L_{\mathrm{m}}$ is:

$$
f \infty \int_{0}^{L_{m}} L P_{L} d L
$$

where $L$ is the loop contour length, $P_{L}$ is the fraction (the probability) of loops of the size $L$. Taking into account that $P_{L}$ is an exponential function of $L$, Eq. 3 can be rewritten as [22] 


$$
f=f_{m}\left[1-\left(1+\gamma L_{m}\right) \exp \left(-\gamma L_{m}\right)\right],
$$

where $f_{m}$ is the maximum DNA amount in the tails (the saturation level $A_{1}+A_{2}$ after a long-time electrophoresis), $\gamma$ is the loop density (the number of loops per total number of kilobase pairs). It should be mentioned that the loop density is related to the loops not larger than $\sim 200 \mathrm{~kb}$ that can be resolved in our experiments. Eq. 4 was used to fit the correlation plots and to estimate the $\gamma$ values.

\section{Results and Discussion}

The nucleoids for the comet assay were prepared starting from cells of four types. Human lymphocytes represent terminally differentiated cells. De-differentiated lymphoblasts were obtained through lymphocyte activation by interleukin 2, which is known to induce prolyferation of lymphocytes [23-26]. The lymphoblasts were cultivated for 24 or $44 \mathrm{~h}$ before the preparation of nucleoids. A flow cytometry cell cycle analysis had shown that a vast majority ( $90 \%$ ) of the 24-h culture was represented by cells at $\mathrm{G}_{0} / \mathrm{G}_{1}$ phases, while the 44 -h culture contained $\sim 60 \%$ of $\mathrm{G}_{2} / \mathrm{M}$ cells (the fractions of $S$ and $\mathrm{G}_{0} / \mathrm{G}_{1}$ cells were about $20 \%$ each). Finally, the Jurkat cell line, originated from leukemic T cells [27], was used as an example of malignant de-differentiated lymphoid cells.

Galleries of typical comets observed after electrophoresis are shown in Fig. 1. There was no difference in the comet appearance between the cell types investigated. The differences were related to the kinetic behavior of two parameters: the relative amount of DNA in the tails and the tail length, which represent the contour length of the largest loops in the tail. The correlation between the two parameters helps to estimate the size distribution of the loops [20, 22]. The kinetic plots of the average relative amounts of DNA in the tails for the nucleoids derived from the four cell types are presented in Fig. 2, the kinetic parameters are listed in Table. The correlations between the DNA amounts and the lengths of the larges loops, which were assumed to fit an exponential distribution of the loop sizes, are shown in Fig. 3.

As it was observed in our previous works [20, 22], the kinetic plots of the average relative amounts of DNA in the tails have a two-step shape for lymphocytes and 24-h lymphoblasts (Fig. 2, A,
Lymphocytes
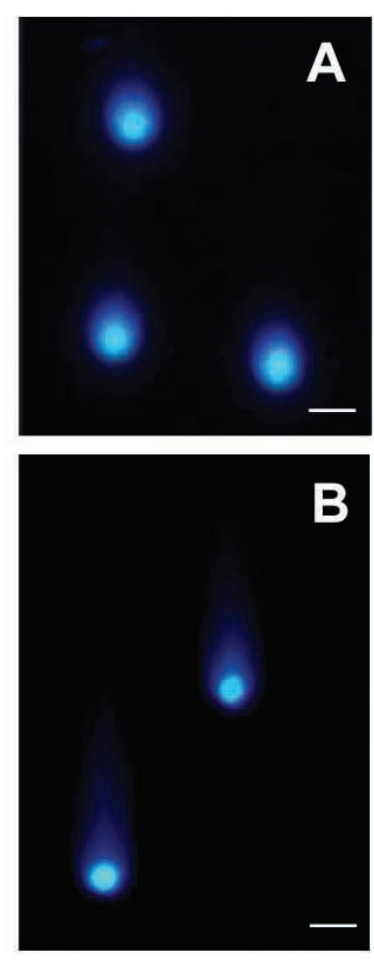

Lymphoblasts 24-h
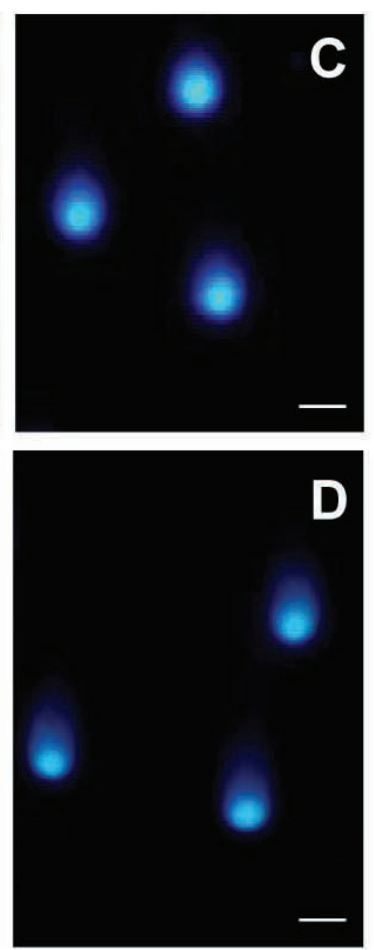

Lymphoblasts 44-h
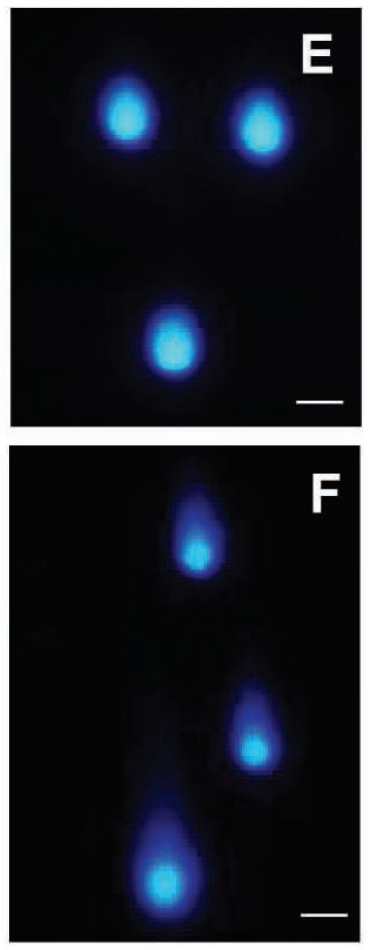

Jurkat

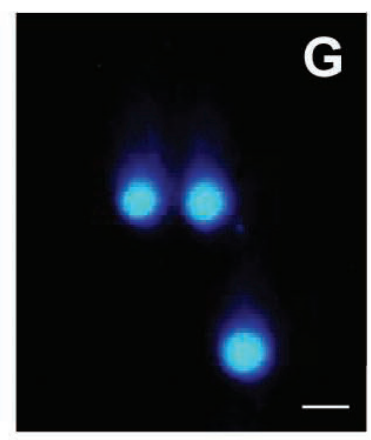

$20 \min$

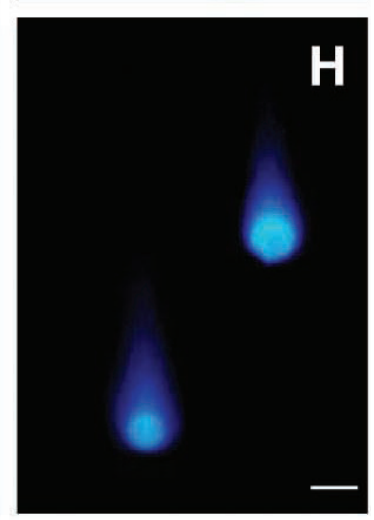

$60 \mathrm{~min}$

Fig. 1. Representative examples of comet images for nucleoids derived from lymphocytes (A, B), 24-h lymphoblast $(\boldsymbol{C}, \boldsymbol{D}), 44-h$ lymphoblasts $(\boldsymbol{E}, \boldsymbol{F})$, and Jurkat cells $(\boldsymbol{G}, \boldsymbol{H})$ being electrophoresed during 20 min (A, C, E, $G)$ and $60 \min (B, D, F, H)$. Bars: $10 \mu \mathrm{m}$ 


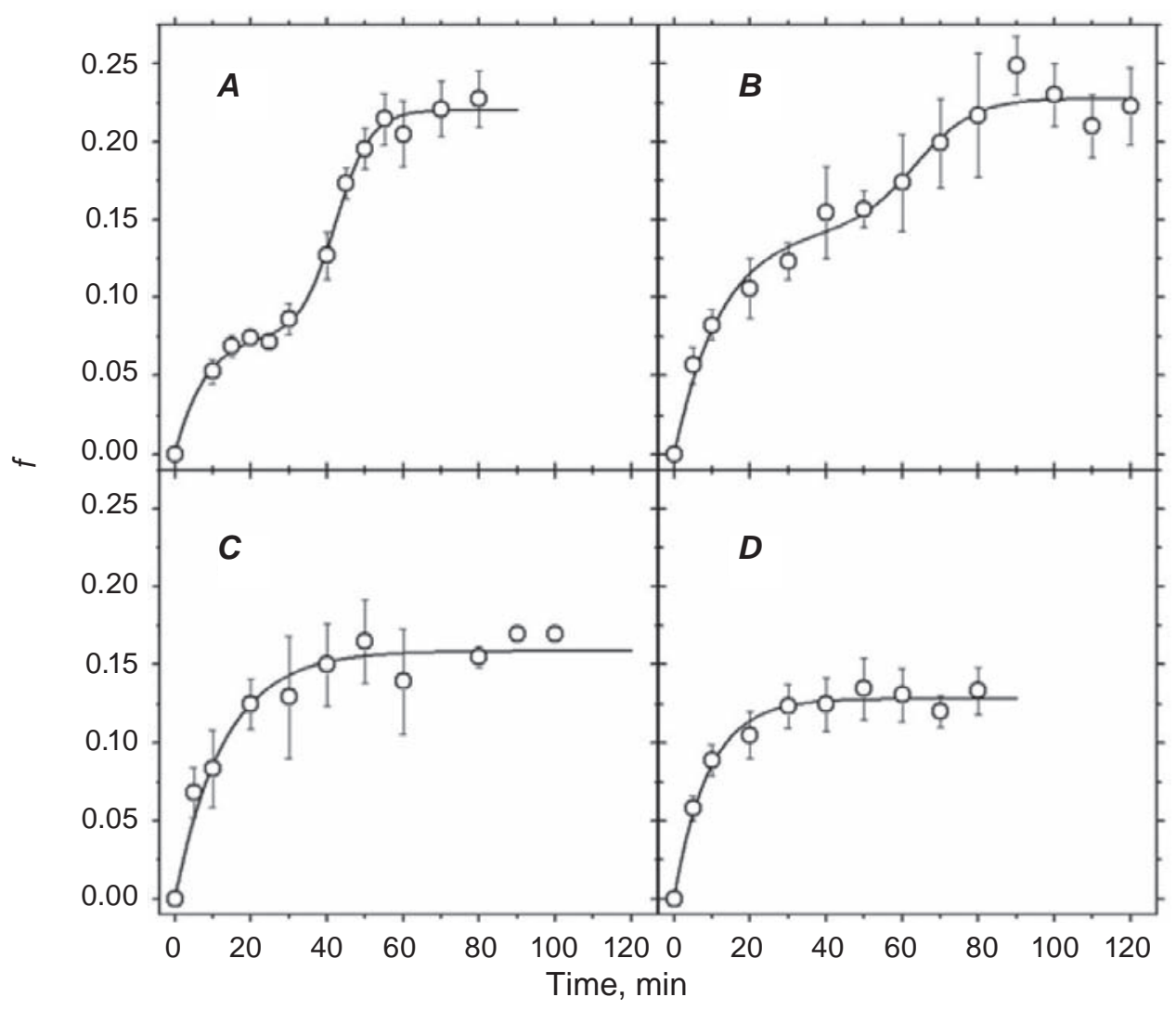

Fig. 2. The average relative amount $f$ of DNA in the comet tails as functions of electrophoresis time for nucleoids obtained from lymphocytes (A), 24-h lymphoblasts (B), 44-h lymphoblasts (C), and Jurkat cells (D). Here and in Fig. 3 below, each point is an average for 5 to 10 independent experiments

$B$ ). We have argued earlier that the first rapid step may be attributed to DNA on the nucleoid surface and the delayed second step represents the exit of inner supercoiled loops [20, 21]. Two differences between the plots were discussed earlier [22]. First, the ratio between the steps changes upon lymphocyte activation: while the total maximum amount of DNA in the tails (and, respectively, the amount of DNA, which do not migrate even after long electrophoresis) remains the same, the amplitudes of the first and second steps becomes, respectively, approximately two-times higher and two-times lower for 24-h lymphoblasts in comparison with lymphocytes. The second difference is related to the rate of migration, which is obviously lower for 24-h lymphoblasts (Fig. 2, A, B, Table 1). We could conclude that activation of transcription, which necessarily occurs when de-differentiation begins and lymphocytes enter the $G_{1}$ phase, is accompanied by a reduction of DNA fraction in the inner loops, which are able to

Kinetic parameters of DNA exit from nucleoids derived from different cell types

\begin{tabular}{l|c|c|c|c|c}
\hline \multirow{2}{*}{\multicolumn{1}{c}{ Cell type }} & \multicolumn{5}{c}{ Parameters } \\
\cline { 2 - 6 } & $k_{1}^{-1}, \min$ & $A_{1}$ & $A_{2}$ & $t_{0}, \min$ & $k_{2}^{-1}, \min$ \\
\hline Lymphocytes & $7.8 \pm 2.9$ & $0.07 \pm 0.01$ & $0.14 \pm 0.01$ & $42 \pm 1$ & $4.6 \pm 0.8$ \\
Lymphoblasts 24 h & $12.5 \pm 3.9$ & $0.14 \pm 0.01$ & $0.08 \pm 0.01$ & $63 \pm 5$ & $7.7 \pm 1.2$ \\
Lymphoblasts 44 h & $12.5 \pm 1.5$ & $0.15 \pm 0.01$ & 0 & - & - \\
Jurkat & $9.0 \pm 0.8$ & $0.13 \pm 0.01$ & 0 & - & - \\
\hline
\end{tabular}




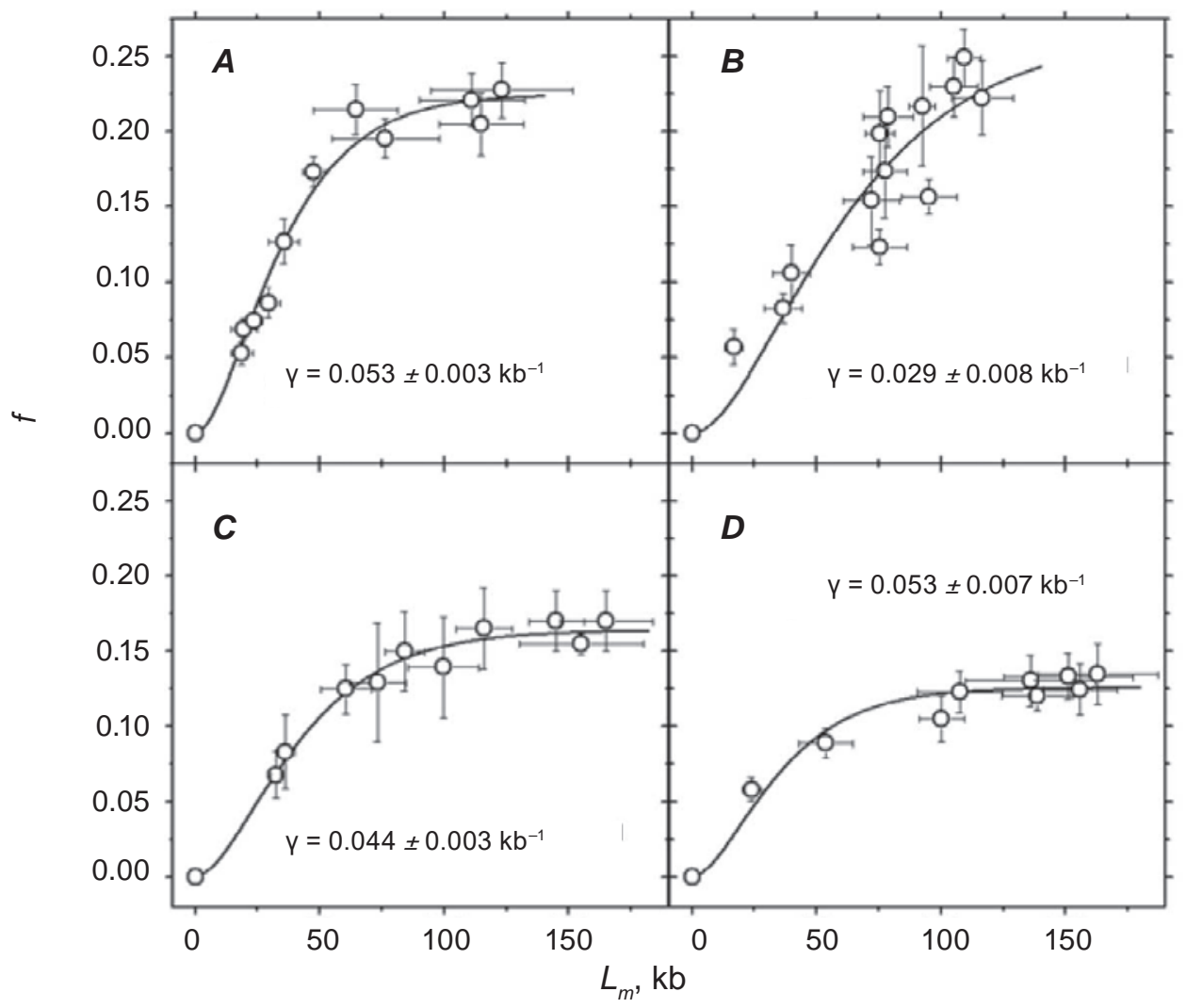

Fig. 3. Correlation between the average relative amount $f$ of DNA in the comet tails and the average contour length of the longest loops in the tail Lm for nucleoids obtained from lymphocytes (A), 24-h lymphoblasts (B), 44-h lymphoblasts (C), and Jurkat cells (D). The values of the linear loop density $\gamma$ are indicated

migrate. Simultaneously, an essential decrease in the linear loop density is observed in 24-h lymphoblasts in comparison with lymphocytes (Fig. 3, A, B).

When lymphoblasts were cultivated for $44 \mathrm{~h}$, more than half of them entered the $G_{2}$ phase (see above). The transcription level in the cells preparing for mitosis is thought to decrease. The kinetic plot in Fig. 2,C shows that the second delayed step disappeared completely for 44-h lymphoblasts (see also Table). Apparently, general transcription decay is accompanied by an increase in the size of the inner loops so that they cannot migrate. Accordingly, the loops which exit at the first steps become larger too: the size of the largest loops in the tails after long-time electrophoresis remains about the same as in 24-h lymphoblasts and lymphocytes (Fig. 3, $C)$. At the same time, an increase in the loop density (almost back to the value obtained for inactive lymphocytes) was observed for 44-h lymphoblasts (Fig.3, C). Thus, so far, an increase in the density of the loops not larger than $\sim 200 \mathrm{~kb}$ seems to be a signature of a decrease in the transcription activity while an increase in the activity is associated with the opposite effect.

All the observations presented above are related to normal - differentiated or artificially dedifferentiated with interleukin 2 -lymphocytes. The Jurkat cells, which are also lymphoid (and morphologically similar to lymphoblasts), are malignant actively proliferating cells [27]. Are changes in the loop organization (if any) the same upon malignant transformation?

For nucleoids obtained from the Jurkat cells, same as for 44-h lymphoblasts, the DNA exit occurred in the one-step mode (Fig. 2, D; Table). The size of the longest loops was also about the same after long-time electrophoresis (Fig. 3, D). In addition, the loop density appeared to be rather high (Fig. 3, $D$ ) for these cells incubated in starvation conditions, which are supposed to keep the cells in a relatively inactive state.

In conclusion, our results obtained for different lymphoid cells show a close relationship between the loop domain organization and cell functional 
state. Two features were found to depend on cell activity. First, proliferating (de-differentiated) cells (lymphoblasts and malignant Jurkat cells), in comparison with terminally differentiated lymphocytes, are characterized by an essential increase of DNA fraction in the loops of large sizes (more than 200 $\mathrm{kb}$ ). This effect is manifested in a decrease of DNA fraction that can migrate in the comet assay. The second effect is related to the linear density of the loops not larger than $\sim 200 \mathrm{~kb}$ : the density appears to decrease upon transcription activation and, respectively, to increase upon inactivation. Our results support also our suggestion to use a relatively simple technique, the comet assay, to detect re-organizations of the loop domains upon cell functional transitions.

Conflict of interest. Authors have completed the Unified Conflicts of Interest form at http://ukrbiochemjournal.org/wp-content/uploads/2018/12/ coi_disclosure.pdf and declare no conflict of interest.

Funding. Acknowledgments. This work was supported by the Ministry of Education and Science of Ukraine (Grant 19BF036-03).

\section{РЕОРГАНІЗАЦІЯ ПЕТЕЛЬНИХ ДОМЕНІВ ДНК У БЛАСТ- ТРАНСФОРМОВАНИХ ЛІМФОЦИТАХ ЛЮДИНИ І ЛІМФОЇДНИХ ЛЕЙКЕМІЧНИХ Т-КЛІТИНАХ ЛIНIÏ JURКAT}

\author{
К. Афанасьєва ${ }^{1}$, В. Олефіренко ${ }^{1}$, \\ А. Мартиняк ${ }^{1}$ Л. Лукаш ${ }^{2}$, А. Сиволоб \\ ${ }^{1}$ Київський національний університет \\ імені Тараса Шевченка, Україна; \\ ${ }^{2}$ Інститут молекулярної біології і \\ генетики НАН України, Київ; \\ ๑e-mail: sivolob@univ.kiev.ua
}

Петельні домени хроматину - важливі елементи як структури хроматину на вищих рівнях його організації, так і системи регуляції транскрипції. У наших попередніх роботах показано, що деякі важливі риси петельної організації можуть бути досліджені за допомогою кінетичного підходу в електрофорезі ізольованих клітин (кометному електрофорезі). Цю техніку застосовано для оцінки петельної організації ДНК лімфоїдних клітин: лімфоцитів людини; лімфобластів, культивованих протягом 24 і 44 год; злоякісних Т-клітин лінії Jurkat. Встановлено два параметри, що варіюють залежно від функ- ціонального стану клітин. По-перше, частка ДНК у петлях великого розміру більше 200 тис. пар основ істотно збільшувалась у (дедиференційованих) клітинах, за проліферації порівняно 3 термінально диференційованими лімфоцитами. По-друге, лінійна щільність петель, розміри яких не перевищують 200 тис. пар основ, знижувалась у транскрипційно активних клітинах та підвищувалась за їх інактивації.

К л ю ч о в і с л о в а: петлі ДНК, кометний електрофорез, лімфоцити, лімфобласти, клітини Jurkat.

\section{References}

1. Dekker J, Marti-Renom MA, Mirny LA. Exploring the three-dimensional organization of genomes: interpreting chromatin interaction data. Nat Rev Genet. 2013; 14(6): 390-403.

2. Rao SSP, Huntley MH, Durand NC, Stamenova EK, Bochkov ID, Robinson JT, Sanborn AL, Machol I, Omer AD, Lander ES, Aiden FL. A 3D map of the human genome at kilobase resolution reveals principles of chromatin looping. Cell. 2014; 159(7): 16651680.

3. Dekker J, Mirny L. The 3D Genome as mModerator of chromosomal communication. Cell. 2016; 164(6): 1110-1121.

4. Hansen AS, Cattoglio C, Darzacq X, Tjian R. Recent evidence that TADs and chromatin loops are dynamic structures. Nucleus. 2018; 9(1): 2032.

5. Sanborn Al, Rao SSP, Huang SC, Durand NC, Huntley MH, Jewett AI, Bochkov ID, Chinnappan D, Cutkosky A, Li J, Geeting KP, Gnirke A, Melnikov A, McKenna D, Stamenova EK, Lander ES, Aiden EL. Chromatin extrusion explains key features of loop and domain formation in wild-type and engineered genomes. Proc Natl Acad Sci USA. 2015; 112(47): E6456-E6465.

6. Fudenberg G, Imakaev M, Lu C, Goloborodko A, Abdennur N, Mirny LA. Formation of chromosomal domains by loop extrusion. Cell Rep. 2016; 15(9): 2038-2049.

7. Nora EP, Goloborodko A, Valton AL, Gibcus JH, Uebersohn A, Abdennur N, Dekker J, Mirny LA, Bruneau BG. Targeted degradation of CTCF decouples local insulation of chromosome domains from genomic compartmentalization. Cell. 2017; 169(5): 930-944. 
8. Rao SSP, Huang SC, St Hilaire BG, Engreitz JM, Perez EM, Kieffer-Kwon KR, Sanborn AL, Johnstone SE, Bascom GD, Bochkov ID, Huang X, Shamim MS, Shin J, Turner D, Ye Z, Omer AD, Robinson JT, Schlick T, Bernstein BE, Casellas R, Lander ES, Aiden EL. Cohesin loss eliminates all loop domains. Cell. 2017; 171(2): 305-320.

9. Wutz G, Várnai C, Nagasaka K, Cisneros DA, Stocsits RR, Tang W, Schoenfelder S, Jessberger G, Muhar M, Hossain MJ, Walther N, Koch B, Kueblbeck M, Ellenberg J, Zuber J, Fraser P, Peters JM. Topologically associating domains and chromatin loops depend on cohesin and are regulated by CTCF, WAPL, and PDS5 proteins. EMBO J. 2017; 36(24): 3573-3599.

10. Vian L, Pękowska A, Rao SSP, Kieffer-Kwon KR, Jung S, Baranello L, Huang SC, El Khattabi L, Dose M, Pruett N, Sanborn AL, Canela A, Maman Y, Oksanen A, Resch W, Li X, Lee B, Kovalchuk AL, Tang Z, Nelson S, Di Pierro M, Cheng RR, I Machol, B Glenn St Hilaire, Durand NC, Shamim MS, Stamenova EK, Onuchic JN, Ruan Y, Nussenzweig A, Levens D, Aiden EL, Casellas R. The energetics and physiological impact of cohesin extrusion. Cell. 2018; 175(1): 292-294.

11. Merkenschlager M, Nora EP. CTCF and cohesin in genome folding and transcriptional gene regulation. Annu Rev Genomics Hum Genet. 2016; 17: 17-43.

12. Hansen AS, Hsieh TS, Cattoglio C, Pustova I, Saldaña-Meyer R, Reinberg D, Darzacq X, Tjian R. Distinct classes of chromatin loops revealed by deletion of an RNA-binding region in CTCF. Mol Cell. 2019; 76(3): 395-411.

13. Tang Z, Luo OJ, Li X, Zheng M, Zhu JJ, Szalaj P, Trzaskoma P, Magalska A, Wlodarczyk J, Ruszczycki B, Michalski P, Piecuch E, Wang P, Wang D, Tian SZ, Penrad-Mobayed M, Sachs LM, Ruan X, Wei CL, Liu ET, Wilczynski GM, Plewczynski D, Li G, Ruan Y. CTCF-mediated human 3D genome architecture reveals chromatin topology for transcription. Cell. 2015; 163(7): 1611-1627.

14. Ji X, Dadon DB, Powell BE, Fan ZP, BorgesRivera D, Shachar S, Weintraub AS, Hnisz D, Pegoraro G, Lee TI, Misteli T, Jaenisch R, Young RA. 3D chromosome regulatory landscape of human pluripotent cells. Cell Stem Cell. 2016; 18(2): 262-275.
15. Kieffer-Kwon KR, Nimura K, Rao SSP, Xu J, Jung S, Pekowska A, Dose M, Stevens E, Mathe E, Dong P, Huang SC, Ricci MA, Baranello L, Zheng Y, Ardori FT, Resch W, Stavreva D, Nelson S, McAndrew M, Casellas A, Finn E, Gregory C, St Hilaire BG, Johnson SM, Dubois W, Cosma MP, Batchelor E, Levens D, Phair RD, Misteli T, Tessarollo L, Hager G, Lakadamyali M, Liu Z, Floer M, Shroff H, Aiden EL, Casellas R. Myc regulates chromatin decompaction and nuclear architecture during $\mathrm{B}$ cell activation. Mol Cell. 2017; 67(4): 566-578.

16. Bonev B, Cohen NM, Szabo Q, Fritsch L, Papadopoulos GL, Lubling Y, Xu X, Lv X, Hugnot JP, Tanay A, Cavalli G. Multiscale 3D genome rewiring during mouse neural development. Cell. 2017;1 71(3): 557-572.

17. Pękowska A, Klaus B, Xiang W, Severino J, Daigle N, Klein FA, Oleś M, Casellas R, Ellenberg J, Steinmetz LM, Bertone P, Huber W. Gain of CTCF-anchored chromatin loops marks the exit from naive pluripotency. Cell Syst. 2018; 7(5): 482-495.

18. Afanasieva K, Sivolob A. Physical principles and new applications of comet assay. Biophys Chem. 2018; 238: 1-7.

19. Afanasieva K, Zazhytska M, Sivolob A. Kinetics of comet formation in single-cell gel electrophoresis: loops and fragments. Electrophoresis. 2010; 31(3): 512-519.

20. Afanasieva K, Chopei M, Zazhytska M, Vikhreva M, Sivolob A. DNA loop domain organization as revealed by single-cell gel electrophoresis. Biochim Biophys Acta. 2013; 1833(12): 3237-3244.

21. Afanasieva K, ChopeiM, Sivolob A. Singlenucleus versus single-cell gel electrophoresis: kinetics of DNA track formation. Electrophoresis. 2015; 36(7-8): 973-977.

22. Afanasieva K, Chopei M, Lozovik A, Semenova A, Lukash L, Sivolob A. DNA loop domain organization in nucleoids from cells of different types. Biochem Biophys Res Commun. 2017; 483(1): 142-146.

23. Kaplan O, Aebersold P, Cohen JS. Metabolism of peripheral lymphocytes, interleukin-2-activated lymphocytes and tumor-infiltrating lymphocytes from ${ }^{31}$ P NMR studies. FEBS Lett. 1989; 258(1): 55-58.

24. Mookerjee BK, Pauly JL. Mitogenic effect of interleukin-2 on unstimulated human $\mathrm{T}$ cells: 
an editorial review. J Clin Lab Anal. 1990; 4(2): 138-149.

25. Mzali R, Seguin L, Liot C, Auger A, Pacaud P, Loirand G, Thibault C, Pierre J, Bertoglio J. Regulation of Rho signaling pathways in interleukin-2-stimulated human T-lymphocytes. FASEB J. 2005; 19(13): 1911-1913.
26. Bachmann MF, Oxenius A. Interleukin 2: from immunostimulation to immunoregulation and back again. EMBO Rep. 2007; 8(12): 1142-1148.

27. Abraham RT, Weiss A. Jurkat $\mathrm{T}$ cells and development of the T-cell receptor signalling paradigm. Nat Rev Immunol. 2004; 4(4): 301308. 